\title{
Women's attitude towards representation of women domestication in advertisement
}

\section{Sikap perempuan terhadap representasi domestikasi perempuan dalam iklan}

\author{
Endah Siswati \\ Department of Doctoral Social Science, Faculty of Social and Political Sciences, Universitas Airlangga \\ Jalan Airlangga 4-6, Surabaya, East Java 60286 \\ E-mail: endah.siswati-2015@fisip.unair.ac.id
}

\begin{abstract}
The persuasive strategies in advertising often use gender-biased signs or languages, which represent women's subordination and domestication. On the other hand, the construction and development of individual gender concepts begin in childhood through the parents, peer groups, schools and mass media socialisation, including advertisements. Thus, how women, who act as wives and mothers, view and respond to female domestication will influence how they socialise gender concepts towards their children. This study examines how the mother of the student at Laboratory Primary School, Malang, view and address the representation of female domestication advertisements in Nova and Nyata tabloids. This qualitative research was conducted in Malang City and using self-researcher as the primary research instrument. Data was collected through Focus Group Discussion (FGD) and interview; then the data were analysed by qualitative analysis method of Miles \& Huberman. This study found that the subjects viewed the tendency of using female models in advertising is reasonable and not a problem as long as fulfil specific criteria. The representation of women's domestication in the domestic sector in the advertisement is also considered reasonable because the representation is the nature of women and selfreflection of women themselves. However, the subjects disagree if the description of women is only as mother who were responsible for household chores. In addition, about the representation of women's domestication in the public sector in advertisements, the subjects stated that they agree if the ads depict the success of men in the public, however, the ads should also describe the involvement and success of women in the public sector and not only describe women as servants.
\end{abstract}

Keywords: attitude; domestication of women; gender-biased; advertisement

\begin{abstract}
Abstrak
Strategi persuasif dalam periklanan sering menggunakan tanda atau bahasa yang bias gender, yang merepresentasikan subordinasi dan domestikasi perempuan. Di sisi lain, konstruksi dan pengembangan konsep gender individu dimulai di masa kanak-kanak melalui orang tua, kelompok sebaya, sekolah dan sosialisasi media massa, termasuk iklan. Dengan demikian, bagaimana perempuan, yang berperan sebagai istri dan $i b u$, memandang dan merespons domestikasi perempuan akan memengaruhi cara mereka mensosialisasikan konsep gender kepada anak-anak mereka. Penelitian ini meneliti bagaimana ibu dari siswa di Sekolah Dasar Laboratorium - Malang, memandang dan membahas representasi iklan yang mendomestikasi perempuan di tabloid Nova dan Nyata. Penelitian kualitatif ini dilakukan di Kota Malang dan menggunakan diripeneliti sebagai instrumen penelitian utama. Data dikumpulkan melalui FGD (Focus Group Discussion) dan wawancara; kemudian data dianalisis dengan metode analisis kualitatif Miles \& Huberman. Studi ini menemukan bahwa subjek melihat kecenderungan menggunakan model perempuan dalam iklan adalah wajar dan tidak masalah selama memenuhi kriteria tertentu. Representasi domestikasi perempuan di sektor domestik dalam iklan juga dianggap masuk akal karena representasi iklan merupakan kodrat perempuan dan refleksi diri perempuan itu sendiri. Namun, subjek tidak setuju jika deskripsi perempuan hanya sebagai ibu yang bertanggung jawab atas pekerjaan rumah tangga. Selain itu, tentang representasi domestikasi perempuan di sektor publik dalam iklan, subjek menyatakan bahwa mereka setuju jika iklan menggambarkan keberhasilan laki-laki di sektor publik, namun, iklan juga harus menggambarkan keterlibatan dan keberhasilan perempuan di sektor publik dan tidak hanya menggambarkan perempuan sebagai pelayan.
\end{abstract}

Kata kunci: sikap; domestikasi perempuan; bias gender; iklan

\section{Introduction}

Advertising persuasive strategies, in its development no longer advertise the function of products or services, but also aimed at creating a product image, such as the image of beauty, elegance, 
masculinity, luxury, harmony, sincerity, loyalty, etc. Efforts to create the image of a product through these advertisements use gender-biased signs or languages. Women in advertisements are often positioned as object signs, not subject signs. Women are also portrayed as the second sex who are socially subordinated before men, and domesticated with their reproductive roles, around managing the household and caring for children. If women are displayed in the public domain, their role is often only as a complementary, with a social position under men.

Conversely, men are represented by self-image and social position that are relatively higher than women and often benefit in the context of advertisements that describe roles in both domestic and public areas. The research of Gornick \& Moran (1971) found that advertisements not only put women in the house but placed them in the kitchen and laundry room. The image of women displayed in advertisements, according to Gornick \& Moran, is a combination of sex objects, wives, and mothers, who are satisfied to look beautiful in front of men. Wagner \& Banos (1973) stated that the image of women who continues to be portrayed in advertisements is "a woman's place is in the home", "women don't do important things", and "women dependent on men". Women according to Wagner \& Bros are rarely displayed in managerial positions and decision makers in institutions such as banks. Courtney \& Lockerez (1979) found that women are rarely shown working outside the home and becoming professionals or top-level business people. Women are depicted as dependent on men and become sex objects or complementary domestic. Women are often featured in advertisements on household products, beauty product and medicine, while men are featured in company advertisements and industrial products, cars, alcoholic beverages, cigarettes, banks, travel and entertainment media.

The research of Widyatama (2006) also found that television advertisements: 1) Highlighted the beauty of the face and body of women, while men were highlighted by aspects of physical strength, 2) Women were portrayed as more emotional, while men were more rational, 3) Women were represented in the domestic sector and male in the public sector, 4) Women are shown as weak and need to be protected, led, controlled and in charge of service, while men are shown as masters, leading, protecting and being served. Siswati (2014) found that advertisements tended to display women in gender-biased themes and ways by utilizing the body, limbs and sensuality of women, or by showing the domestication of women. Domestication of women in these advertisements is realized by highlighting the role of women as wives and housewives who are responsible for education and care for children, health nurses, nutrition and family consumption guarantor, as well as responsible or executing domestic work.

Domestication of women in advertisement representation is divided into two categories, namely the domestication of women in the domestic sector and public sector (Kasiyan 2008, Siswati 2014). In the context of domestication in the domestic sector, the ad represents women as a lower figure than men, who are in charge of serving and caring for their husbands, children, families and doing household chores. Furthermore, women are used as a sign of products for kitchen needs, cleaning and maintenance of clothing product, family health care products, child care product, etc (Kasiyan 2008, Siswati 2014:183).

According to Kasiyan (2008), the term domestication of women, in its development, is not limited to work activities in the household, but also used in the public sector. The type of work that is considered domesticating is work that is not paid and is more voluntary. If the work of women in the public sector is professional and well-paid, then domesticating means that women do work that is only to help the leader (male), not the control holder (secretary for example), or work that is lower than men ( school teachers whose education level is still low, not lecturers or professors).

On the other hand, The Social Learning and The Cognitive Social Approach states that individuals get socialization of the concept of gender since childhood through parents, then groups of peers, schools, and mass media, where advertisements included (Matlin 2004). If messages that are socialized to children are gender biased, subordinate and domesticate women, then patriarchal values will continue to be internalized, considered true and natural, so that they are passed on to the next generation. If so, then the deconstruction of patriarchal culture and the division of traditional gender roles will be 
difficult, so justice and gender equality are increasingly difficult to achieve (Siswati 2014:181). So, how do a woman themselves, who act as wives and mothers at the same time, view and respond to the representation of women's domestication in advertising, becomes important. Their views and attitudes will influence how they socialize the concept of gender in their children, and therefore this issue is worth investigating.

Previous research on response and audience attitudes towards women's representation in advertisements was found. Lundstrom \& Sciglimpaglia (1977) measure male and female attitudes towards the type of women's roles in advertising. They found that female respondents were more critical of responding to portraits than men. Respondents tended to believe that advertisements portray women in an attacking, unimportant, and home-oriented manner, but this belief does not affect their intensity to buy the product advertised. The researchers also found that women's attitudes were not too critical, even though their attitude towards the portrait of women's sexual roles in advertising was not good compared to men's attitudes. Women also tend to feel that men and women are not accurately portrayed in advertisements.

Duker \& Tucker (1977) researched by showing female students, advertisements featuring various female roles such as the role of mothers, sex objects, housewives, glamorous girls, working mothers, modern women, and professional women. Respondents were asked to evaluate the roles displayed. The female students' evaluation of the roles in the advertisement did not differ between the two groups classified as feminists and non-feminists. Whipple \& Courtney (1980) examined women's responses to several advertisements that represented traditional and progressive women's sexual roles. They found that the progressive role of women was equally favoured, or preferred over traditional women's roles. Respondents' level of dislike increased when advertisements represented excessive roles of women, regardless of whether the advertisements featured the role of traditional and progressive women.

Zimmerman \& Dahlberg (2008), measure women's attitudes towards advertisements that objectify women sexually. Survey research that combined these two previous studies (Ford, LaTour, \& Lundstrom 1991, Mittal \& Lassar 2000), was aimed at 94 female students. The results of the study showed significant attitudinal changes from previous studies. Respondents agreed that women were portrayed as sex objects in advertisements, but they were less offended by portrayals in advertising, compared to female respondents in 1991. Research also showed that respondents' attitudes toward advertising have little effect on purchase intention. This is a very significant change compared to women's attitudes in 1991. Bakir, Blodgett, \& Rose (2008) examine whether male and female adolescents differ in their attitude toward advertisements that combine attributes of an individual or communal gender roles. The results of this study indicate that marketers can target boys and girls with the same set of ads. However, advertisements must convey individual themes if advertisements are targeted at older teenage girls, and communal themes if targeted at younger teenage girls.

This research was conducted to increase the number and fill in the blanks of previous studies about the response and audience attitudes towards advertising, by focusing research on the question of how women who act as mothers, view and respond to representations of women's domestication in advertisements.

\section{Research Method}

This study uses a qualitative approach because of: 1) This research examines expressions, opinions, knowledge, perceptions, feelings, and attitudes, 2) Use researchers as the primary research instruments, 3) Use qualitative data collection techniques, and 4) Rely on narrative forms (words and language) in explain the meaning and reality to be presented to the reader. Descriptions and exposures of data in the form of numbers and tables in this study are intended to make reality easier to read and understand.

The focus of this study is women's attitudes towards the representation of women's domestication in commercial display advertisements in Nova tabloids and Nyata tabloids. These two tabloids were 
chosen because they are printed media for women with two large circulations in Malang City, so it is assumed that the number of readers and the advertisement version involving women is more than other print media.

The research subjects were selected purposively, namely female parents/guardians of students in the Laboratory Elementary School, Universitas Negeri Malang. The choice of research subjects was based on the idea that the construction and development of concepts and individual gender roles began in childhood so that the media that first socialized the concept and role of gender in children were parents. Parents' attitudes and beliefs about gender concepts will influence how they socialize the concept of gender in their children.

The research was conducted in the Laboratory Elementary School, Universitas Negeri Malang (State University of Malang), because at the time of the research, researchers were parents, as well as administrators of the parents of students in Elementary School Laboratory so that researchers had good friendships with the research subjects. Cresswell (1994) states that personal and emotional proximity factors are needed to get the actual information. The experience of the researcher, which makes him familiar with the topic, setting, or subject matter (informants), will sharpen the interpretation of research data so that the association and friendship of researchers with research subjects are expected to facilitate researchers in understanding their attitudes.

Data collection is done by conducting Focus Group Discussion (FGD) and interviews. There are six key questions that were used as guidelines in conducting FGDs and interviews, namely 1) How the research subjects responded to the tendency to use female models in advertisements, 2) How the research subjects responded to the depiction of women in advertising, 3) What the research subjects thought and felt seeing depictions of women in advertisements, 4) Which advertisements and how they attract the most attention and give a deep impression on the research subjects, 5) How the research subjects assessed the way in which message was delivered in the advertisement, and 6) How women should be portrayed in advertisements.

The FGD was held at the Post-Graduate Building, Universitas Brawijaya (Brawijaya University), Malang and was attended by 26 research subjects who were all Muslim (100\%), almost all of them were Javanese (92\%), aged between 20-50 years (96\%), with their last high school education/Diploma $(46 \%)$ and Bachelor (46\%). The majority are married (84\%), and half of the research subjects $(50 \%)$ are women who work as employees or are self-employed.

The FGD implementation begins with the presentation of the researcher in front of the research subjects to explain the background and objectives of the study and explain the results of ads analysis in the Nova and Nyata tabloids that have been done by researcher previously (Siswati, 2014). In previous research, researchers collected 22 editions of Nova and Nyata tabloids, then recorded and analyzed a total of 819 display advertisements, and found that 214 advertisements (26\%) represented the domestication of women. The 214 advertisements are in part the same version of the ad that was loaded several times. The versions of advertisements that domesticate women in the Nova and Nyata Tabloid are 96 versions. The researchers selected 50 versions of these advertisement (taking into account the diversity of themes), and added five versions of the ads representing male gender positions and roles (as comparative advertisements), as a means of knowing the attitudes of research subjects towards women's domestication representations in advertisements. All research subjects followed this initial presentation and then they were asked to look at 50 ad photos that represented women domestication and five comparative advertisements, in one closed room using LCD. After the presentation, researchers divided the research subjects into two discussion groups, each of which was guided by a moderator assisted by a secretary. The moderator guides the discussion using the key question guide. The FGD process is documented using a digital camera and tape recorder, as well as manually recorded by the secretary of each group.

Follow-up interviews were conducted individually on several FGD participants to collect more detailed data to complete the data obtained by researchers through the FGD. Interviews are conducted in the 
home of the research subject or at work, using the same question guide. Some interviews were recorded using digital cameras, and others were recorded manually in field notes. The analytical method used to analyze the attitudes of women in the subject of the study was the qualitative analysis of interactive models from Miles and Huberman. This analysis consists of three main steps, namely data reduction, data display, then drawing and verifying conclusions (Miles \& Huberman 1994, Pawito 2007).

\section{Result and Discussion}

Women's attitudes towards the representation of women's domestication in advertisements are divided into three parts, namely, 1) Attitudes towards the tendency to use female models in advertising, 2) Attitudes towards representation of women's domestication in the domestic sector, and 3) Attitudes towards the representation of women's domestication in the public sector in advertisements.

\section{Attitudes towards trends in using female models in advertising}

The tendency of the use of female models in advertising, according to research subjects because women are considered beautiful, more attractive and pleasing to the eye compared to male models, so using a female model will make the ad more attractive. Overall the opinions of the research subjects are summarized in the Table 1.

Table 1.

The opinions of research subjects about the reasons for using female models in advertisement

\begin{tabular}{lc}
\hline \multicolumn{1}{c}{ Research subjects statement } & $\begin{array}{c}\text { Number of } \\
\text { statements }\end{array}$ \\
\hline The use of female models in advertisements corresponds to the type of product advertised & 6 \\
Female models are more beautiful, more attractive and more pleasing to the eye than male & 5 \\
models & 2 \\
Advertisements will be more interesting if using a female model & 1 \\
Advertising will be strange if the model is replaced with a male model & 1 \\
Advertisements are advertised on female tabloids so that they use female models & 1 \\
Advertising uses a female model because generally purchasing decisions are in the women's & 1 \\
\hline
\end{tabular}

Table 2.

Attitudes of research subjects towards using female models in advertisement

\begin{tabular}{lc}
\hline \multicolumn{1}{c}{ Research subjects statement } & $\begin{array}{c}\text { Number of } \\
\text { statements }\end{array}$ \\
\hline It is natural and legitimate to use a female model as long as matching to the product & 8 \\
advertised (the product advertised does have something to do with women or is a woman's \\
need). \\
It does not matter to use the female model as long as the reason for using the female model \\
in advertising is reasonable and not making it up. \\
It does not matter to use female models as long as women displayed within the limits of \\
modesty and do not exploit the physical beauty and sensuality of women. \\
No problem using female models as long as women are not suggested to be lower than \\
men.
\end{tabular}

The research subjects stated that the tendency to use female models in advertising is fairness and does not matter, as long as it meets specific criteria (Table 2). Research subjects like the female model used in advertisements that describe the fabric of affection in the family, especially those that describe the closeness between mother and child, as long as they dress modestly and do not exploit the female body. Ads that display the figure of mother and child, according to the research subject are deliberately made to describe the patience, sincerity, closeness and affection of the mother and child. The research subjects realized that men could have the same closeness and intimacy, but they argued that most children were closer to their mothers. The opinions and attitudes of the research 
subjects regarding the use of the female model in the advertisement of child and household needs are presented in the Table 3 and Table 4.

Table 3.

Opinions and attitudes of research subjects towards using female models in children's needs advertisements

\begin{tabular}{lc}
\hline \multicolumn{1}{c}{ Research subjects statement } & $\begin{array}{c}\text { Number of } \\
\text { statements }\end{array}$ \\
\hline The female model is suitable to be displayed in advertisements related to children or children's & 7 \\
needs. & 7 \\
Liking a female model is displayed in advertisements that describe the fabric of love in the & \\
family, especially about the closeness between mother and child. & 7 \\
Advertisements relating to children and expressions of affection in the family should also \\
involve men (father/husband) so that advertisements are better and reflect a harmonious \\
family.
\end{tabular}

Table 4.

Opinions and attitudes of research subjects towards the using female models in advertisement of household needs products

\begin{tabular}{lc}
\hline \multicolumn{1}{c}{ Research subjects statement } & $\begin{array}{c}\text { Number of } \\
\text { statements }\end{array}$ \\
\hline It is natural to use female models in household products ads. & 4 \\
Advertisements of household products can use female and male models together. & 10 \\
Objection or disagree if only women are shown in advertisements on household products, & 4 \\
men should also be involved in it. & 10 \\
It doesn't matter that advertising uses a male model, not strange, not inferior to & 2 \\
advertisements that use female models. & \\
\hline
\end{tabular}

Women's attitudes towards representation of women's domestication in the domestic sector in advertisement

The research subjects stated that what was represented in the advertisement described the nature of women and the duties of Eastern women. They also feel proud because the representation of advertisements makes them look perfect. The attitude of the research subjects is summarized in the Table 5 and Table 6.

The research subjects liked how advertising emphasized the closeness of relationships and affection between mother and child. They feel happy, touched and proud of the portrayal of women as mothers in advertisements. They argue that women who call themselves mothers should do things like women do in advertisements. The ideal mother is the mother as described in the ad. Although the research subjects liked how advertisements portray women as mothers, they argued that men should also be featured in advertisements that illustrate parental and child affection, also in childcare activities. According to them, this will give a more beautiful impression, show a harmonious picture of the family, keep the father figure, and give an example for men not to be reluctant involving in childcare activities, so that the representation of the advertisement is in accordance with the developing reality in society today.

\section{Women's attitudes towards representation of women's domestication in the public sector in advertisements}

The research subjects stated that men were more suitable to be leaders in advertisements because they considered that the position of men was above women. However, they also want the advertisement to show the women's involvement and success in the public sector and not only show women as housekeepers, or just as servants. 
Table 5 .

Opinions and Attitudes of Women towards Representations of Women's Domestication in the Domestic Sector in Advertisement

\begin{tabular}{lc}
\hline \multicolumn{1}{c}{ Research subjects statement } & $\begin{array}{c}\text { Number of } \\
\text { statements }\end{array}$ \\
\hline What is described in the advertisement is reasonable because what is shown in it is indeed & 2 \\
the duties of Eastern women? & 5 \\
The picture shown in the advertisement is the nature of women, namely being a housewife. & 6 \\
Proud of the image of women in advertisements because in the women are seen as perfect, \\
great and versatile, more than men. \\
What is described in the advertisement reflects what can be done by herself. \\
No objection and no problem the woman was described as struggling with household \\
chores, including cleaning the toilet because she did the same thing. \\
The representation of women in advertisements still describes the reality in society, even \\
though there are many women who carry out domestic and public tasks at once.
\end{tabular}

Table 6.

Women's Opinions and Attitudes towards Representation of Women's Domestication in the Domestic Sector in Advertisements - Women as Housekeepers

\begin{tabular}{lc}
\hline \multicolumn{1}{c}{ Research subjects statement } & $\begin{array}{c}\text { Number of } \\
\text { statements }\end{array}$ \\
\hline $\begin{array}{l}\text { Do not agree with the description of women in advertisements because the role of women is } \\
\text { not only as a housewife but also many who act as career women. }\end{array}$ & 6 \\
Objection and concern about the image of advertisements that suggest that domestic work \\
and domestic affairs are only the duty and responsibility of women. \\
Advertisements will be better, more balanced, fun to look at, and impress harmony if male \\
involvement in doing housework is also shown. \\
$\begin{array}{l}\text { Like and be impressed with the household needs products advertisements that use male } \\
\text { models, because it gives the impression that men/husbands are well willing to be involved in } \\
\text { housework. }\end{array}$
\end{tabular}

Table 7.

Opinions and attitudes of women towards the representation of women's domestication in the public sector in advertisement

\begin{tabular}{l} 
Research subjects statement \\
$\begin{array}{l}\text { Number of } \\
\text { statements }\end{array}$ \\
Men are more suitable to be a leader in advertisements because the position of men is \\
considered above women. \\
No matter the advertisement describes the success of men in the public sector. \\
Women should also be described as successful in the public sector in a variety of profes- \\
sions such as men to be balanced and in accordance with reality. \\
The image in the advertisement impresses women only as servants. \\
\hline
\end{tabular}

\section{Trends in using female models in advertising}

\section{The use of female models for household needs product advertisements is reasonable}

The research subjects viewed that the tendency to use the female model in advertising was fairness as long as the product advertised had something to do with women or women's needs (Table 2). They see that the female model is suitable for household needs (Table 4) and children's needs advertisements (Table 3). The phenomenon of the tendency of using female models in household products advertisement, according to Budiman (2006) is because family and housewifes are the most suitable targets for advertisements on consumer products ranging from food products, vitamins and medicines, child care products to cars and real estate. Changes in family function from the production unit to the consumption unit, causing advertising to be freer to create an ideal family image for the benefit of producers. This image does not shift away from cultural stereotypes about the role of conventional mothers and fathers. 
In the advertisement representation, there is almost no family without the presence of a mother, while the father figure may not be present explicitly. In this regard, Suwasana (2001) states that women have indeed become commodities in advertising communication. Women become a tool to get and confirm the attractiveness of a product. Advertising communication no longer only touches on the function of a product but extends to touch on the concept of gender. Femininity or masculinity is often used as a tool to make commodities or products have a certain value. Suwasana (2001) states that" brave," "masculine," "male", "exclusive" have become sticky idioms with commodities such as automotive, cigarettes, supplements, strong herbal men, perfumes, and so on. While products such as soap, shampoo, kitchen and household appliances to electronics, are described as commodities that are closely related to the region of femininity. The closeness of a commodity to the region of femininity is shown among others by using female models in advertising.

\section{The female model is suitable for children's needs products advertisements}

The research subjects said that the female model suitable to be displayed in product advertisements for children's needs. They like the female model used in advertisements that describe the fabric of affection in the family, especially about the closeness between mother and child (Table 3).

Women are predestined to have reproductive organs that enable them to experience menstruation, pregnancy, childbirth and breastfeeding. It is this nature of women that makes people believe that because women give birth to children, they are also the most appropriate to care for them. This view is supported by the Theory of Nature (Budiman, 1985), who believes that biological differences between men and women cause psychological differences between the two, and then these psychological differences raise the different roles. Women because their biological nature is believed to have gentle, motherly, meticulous, patient, etc., so that makes her suitable to carry out the role of caring and nurturing. While men because of their physical nature have strong, hard, rational, resilient qualities, so they are considered suitable for carrying out roles outside the home, earning a living to support their families. Marwell (1975) states that in one family, two functions must be developed, namely educating children and producing food. Because the family consists of men and women, one function is given to one sex, and another function is given to the other sex. Marwell (1975) explains that women get a function in the household environment because women have to carry out the functions given by nature to them, to conceive and give birth. When women conceive, give birth and care for a newborn child, it will be dangerous for them to work hard outside the household so that it is better for women to work in the household environment and educate their children to be big. Meanwhile, men work outside.

Although the research subjects argued that women were suitable to be displayed in advertisements related to children and children's needs, they were of the view that men should also be shown in advertisements. They realize that men are capable of carrying out childcare roles. Related to this awareness, Fakih (2010) states that the psychological traits of men and women are socio-cultural constructs which are believed to be natural. These psychological traits can be exchanged, and change from time to time, from one place to another, including from one class to different classes of society. Thus, men can have a gentle, patient, fatherly nature, which makes him capable of carrying out the role of caring and nurturing children.

\section{Women are beautiful, more attractive and more pleasing to the eye}

The research subjects of the study stated that it was natural for female models to be used in advertisements because women do look beautiful, more attractive and pleasing to the eye compared to men. Using a female model will make the ad more interesting (Table 1).

A good advertisement, according to Kasali (1993), must at least fulfil several elements summarized in the AIDCA Formula, namely Attention, Interest, Desire, Conviction and Action. A good advertisement must be able to attract the attention of the audience, arouse their interest to know more about the product or idea advertised, drive the desire to own or enjoy the product, and be able to get rid of 
doubts, while convincing them that the advertised product meets their needs. A good advertisement must be able to persuade the audience to move to take the expected action. Advertisers in their efforts to attract the attention of audiences and embed product images often choose to use women as object signs or icons. Hagijanto (2000) states that many advertisements utilize female body figures or parts as attractors of views and create certain images. Ads generally take advantage of femininity, popularity, attractiveness and charm of women, including the sexual side. Advertisements also use women in complementary intimacy interactions, where female sexuality and sexual attraction are demonstrated and exploited in interactions with the opposite sex.

Yuris (2008) said that because of the beauty, the women are often displayed in advertisements even though sometimes their presence is forced. Women also tend to be chosen more often when the range of the existence of male and female figures in advertisements is equal. According to Yuris, advertisers and advertising agencies believe that using female characters in advertisements is an aesthetic demand to grab the attention of the public. This method is considered more effective. However, using male models in advertisements that are usually played by female models do not necessarily make the ads less attractive. Evidently, in this study, some research subjects liked and were impressed with advertisements using male models. The research subjects assessed that the use of male models in advertisements gave the impression that men cared and were willing to be involved in women's work (Table 7). Furthermore, the most important thing in producing advertisements depends not only on the model figure, but also on the strength of the creative strategy concept, including the novelty and uniqueness of ideas or themes, the strength of copy writing, the dynamism of concepts in accordance with the development of the situation, the advertisement production process itself, etc (Kasali 1993, Wibowo 2003).

\section{The ad will become strange if a male replaces the model}

Some research subjects stated that the use of male models in household product advertisements was not strange, it was not a problem and no less good than advertisements using female models (Table 4). However, there are research subjects who said that advertisements related to household products would be strange if they are replaced by male models (Table 1). Why is it strange? The representation of women and men in advertisements in the mass media, both printed and electronic, has not changed much in the long term. Relationships, positions and roles of women and men are displayed in a similar theme, namely women are placed in the domestic and male in the public sphere, men as ordinate and women as subordinates, men as subjects, and women as an object. Women are often represented as signs of kitchen products, cleaning and care products for clothing, family health care products, and child care products. Women are also used as object signs in advertisements that are only complementary to men's work or are displayed with a type of work that is socially stratified lower than that of men. Meanwhile, men are often placed as dominant figures in social roles that are meaning productive (Gornick \& Moran 1971, Courtney \& Lockeretz 1971, Widyatama 2006, Kasiyan 2008, Siswati 2014). Thus, the audience has become accustomed to seeing the representation of advertisements that show the activities of women in the domestic area, carrying out their roles as housewives, and seeing the activities of men in the public domain with their productive roles. Changes in the theme of advertising in representing relationships, positions and roles between women and men out of habit beforehand, might lead to strange feelings and as a result, the new theme will seem strange and stiff.

The opinions of the research subjects are also thought to be influenced by the research subjects understanding and beliefs about the division of traditional gender role (Table 6). Socialization in a long period about the gender roles of women in the domestic area has led to the belief in the community that women are responsible for the overall implementation of domestic work. While for men domestic work is not only considered not their responsibility but even in many traditions, men are taboo and are prohibited from being involved in domestic work (Kusujiarti 2006). Thus, the representation of advertisements that are not in harmony with the concept of the division of traditional gender roles will be considered as doubtful, because men and women are displayed in spaces that are not their territory. 
The values of Javanese culture that still exist in society are also thought to influence the opinions of research subjects, who state that the image shown in the advertisement is indeed the duties of Eastern women and in accordance with the nature of women, as housewives (Table 6). The ideology that emphasizes that the main role of women is around the house as a wife and mother has been socialized for centuries in Javanese cultured societies and internalized by Javanese women. In various expressions it can be traced to the notion that Javanese women's functions are cooking (masak), dressing up (macak), giving birth (manak) (Sukri \& Sofwan 2001, Kusujiarti 2006). The role of women is not far from the affairs of the kitchen, wells and mattresses. Women are considered as a complete social and cultural figure if they have carried out their roles as good mothers and wives, who give their energy and attention to the interests of the family without expecting rewards, prestige and power (Kusujiarti 2006).

In contrast, the primary role of men in Javanese culture is as the main ruler of the household who has the greatest privileges and authority in the family. Husband or father is the protector and maker of important decisions in the family. Other family members including wives must submit to the central figure (Kusujiarti 2006). By such cultural values, the representation of advertisements depicting men who are involved in domestic affairs, interfering in childcare and managing the household will be considered unusual, inappropriate, and strange.

Religious values also take a role in influencing the opinions of research subjects. In Islam, men are Qawwam (leaders), and women are Qaanitaat (obedient) because Allah has exaggerated some of them (men) over others (women). God has embellished men physically, giving them a stronger body to support them doing work outside the home, while women preferably stay at home to provide a stable environment for the growth of children. Men in Islamic values should provide for their families, and become leaders in their homes, while wives are their supporting pillars. Men lead women because they function to provide protection and security, work and make money, while women themselves do need protection from men so they can still exist (Fakih 1966, Muhammad 2001, Kusujiarti 2006, Mufidah 2010). Some Islamic values relating to the position of men and women believe that men occupy a superior position over women because men are seen as superior to women in terms of rationality, firmness, enthusiasm, courage, and dexterity. Men are also said to be superior because their knowledge is broader and their ability to work hard is better (Fakih 1966, Kusujiarti 2006). With this basis, the representation of the ad that describes the situation outside the framework of the religious belief, will look inappropriate.

\section{Attitudes towards representation of women's domestication in the domestic sector in advertising}

\section{Advertisements represent the nature of women}

Discussing the nature of women cannot be separated from the discussion of differences in the concepts of sex and gender. Handayani (2006), Agustino (2008), Kasiyan (2008), Fakih (2010), understand sex as a sex division determined based on differences in biological characteristics inherent in particular sex. Sexual differentiation of men and women is mainly related to reproductive tools and functions between the sexes. Biologically the reproductive organs attach to men and women forever, are universal, permanent, unchanging, and their functions cannot be exchanged because they are God's nature. Thus the nature of women is to have various biological characteristics and reproductive organs such as the vagina, uterus, breast, and undergo reproductive functions such as menstruation, producing egg cells, pregnant, giving birth and breastfeeding.

Handayani (2006), Agustino (2008), Kasiyan (2008), Fakih (2010), said that the concept of gender is attached to men and women by social and cultural environments, evoke several stereotypes about the social role and cultural role of men and women. For example, women are considered weak, emotional, gentle, motherly, while men are considered strong, rational, male, mighty. These properties can be exchanged and changed from time to time. Agustino (2008), states that gender is related to differences in the nature, status, roles, functions, duties and responsibilities of men and women as a result of community-agreed construction, and can change according to the times. Agustino (2008) 
explains that sex cannot be changed and exchanged, applies throughout the ages, and everywhere, and is God's provision, while gender can change and be exchanged, depending on time and local culture, and not God's nature but human-made.

Referring to the differences in understanding of sex, gender, and the nature of women, it can be said that the research subject stating that 1) Representation of women in selected advertisements shows the nature of women, 2) The nature of women as housewives, 3) Women's nature is in the kitchen (as listed in Table 4), 4) It does not yet understand the meaning of nature and nature of women. It needs to be emphasized that the advertisements shown to the research subjects are advertisements that represent women in their characteristics which are considered feminine (gentle, painstaking, patient, dexterous, conscientious, full of affection), as well as showing women acting as wives or mothers households that are responsible for the implementation of household affairs and child care (Siswati 2014). The advertisements shown do not describe the nature of women but describe the roles, functions, duties and responsibilities of women who are socially and culturally constructed.

Misunderstandings experienced by the research subject were allegedly also influenced by the individual learning process throughout his life about the differences between men and women. Socialization and internalization of the physical and psychological differences between men and women in society causes people to believe that women should live in a domestic environment to give birth and raise children and take care of the household, while men go outside to support their families (Budiman 1985, Kasiyan 2008, Fakih 1966, Beauvoir 2016). The division of work (role) sexually which takes place in a very long time, is continued between generations, even reinforced by state rules and religion, causing people to tend to think of it as something natural or nature by God (Handayani 2006).

\section{Advertisement representation shows the greatness of women}

Sexual division of labour or so-called traditional gender role division, regulates women to live in a home environment (domestic) and do household chores, while men outside the home (public) to make a living (Budiman 1985, Abdullah 2006, Kasiyan 2008, Handayani 2006, Mufidah 2010). But in its development, along with the development progress and feminism movement, the level of women's participation in the workforce has increased, both in terms of the number and types of jobs that women can enter (Indrayanti \& Lisna 2007, Intan 2014). The involvement of women outside the home indicates that women have tried to reconstruct the history of their lives by establishing a new identity for themselves, not only as mothers or wives but also as workers and career women. The expansion of women into various fields of life has occurred and is considered a sign of "victory" for women (Abdullah 2006, Intan 2014).

Statement of research subjects that they feel proud of the representation of women in advertisements (as listed in Table 6), among others, is driven by the awareness that women can play in two areas at once, public and domestic, while men generally only move in public areas. Advertisement representation is favoured because it is considered to show women as a great figure who can carry out various roles, ranging from childcare, kitchen management and household management, to working for a living. The pride of the research subjects made them unaware or not felt that the representation of advertisement domesticated women. Pride of research subjects also indicates that they do not realize that women have carried a double burden because women's involvement in the public domain does not change and reduce their reproductive role in the household (Kasiyan 2008, Handayani 2006, Mufidah 2010, Diamond 2014).

\section{Advertisements represent reality}

The research subjects felt that the representation of advertising reflected what they were able to do themselves (Table 6). This personal experience, among others, causes them to judge that ad representation represents reality in society (Table 6). Often advertisers move the social fact or portrait of human life in a society that is often found in everyday life into the representation of 
advertisements by packaging it in a slice of lifestyle, becoming another cause. Although the actual image of reality represented in the advertisement is a false reality, often these representations are considered as a reflection of original reality (Suwasana 2001, Ritzer 2010). Advertisers intentionally base their creative advertising strategies by moving social codes into ad representation as part of efforts to eliminate cultural alienation and the creation of social harmony. The action is also intended to bridge the field of experience and frame of reference that develops in the community, especially the experience of mothers so that the message of advertising is easier to understand, more effective and capable of impacting as expected (Widyatama 2006).

\section{Women are not just housewives}

Research subjects disagree with the representation of advertisements that describe women only as housewives because the reality is that many women play career women (Table 7). Women are no longer only engaged in domestic areas, but also in public areas (Abdullah 2006). The involvement of women in the public world is increasing, with diverse types of jobs and positions, including in sectors that are generally male-dominated (Indrayani \& Lisna 2007, Intan 2014).

\section{Women like the representation of advertisements that describe the closeness of mother and child}

In the view of the researcher, the attitude of the research subjects who liked advertisements describing the closeness of mother and child (Table 3) was influenced by; 1) Understanding and belief that the responsibility of caring for children is indeed in the hands of mothers (Budiman 1985, Fakih 1966, Kusujiarti 2006, Mufidah 2010), 2) Advertisements are intentionally created using the slice of slice, photographing fragments of life that can be found in daily routine, so the research subjects feel that what is displayed in advertisements is an image of reality (Suwasana 2001), and 3) Advertising deliberately utilizes feminine stereotypes that are believed by society by highlighting ideal traits for the role of a mother, namely soft, painstaking, patient, caring, caring, agile, full of love and willing to sacrifice (Fakih 1966, Kusujiarti 2006, Handayani 2006, Kasiyan 2008). These things are thought to cause research subjects not to feel and not be aware of the domestication of women in the advertisement representation, and even enjoy it as something that is proud and touching.

The research subjects did not realize that the portraits of life displayed in advertisements were almost always an ideal picture, more beautiful than the reality referred to because advertising is a work of art which among others aims to evoke a beauty experience. Ads often also deliberately touch the affective sides of the target to get attention and sympathy, which aims to cause imitation actions, namely the purchase or use of products (Kasali 1993, Wibowo 2003).

Furthermore, even though the research subjects liked how advertisements portray the role of women as mothers, they argued that men should also be displayed in ads that illustrate affection for children and involve them in caring for children to fit the evolving reality in society (as listed in Table 3). Opinion of the research subjects, related to; 1) Women's personal experience about the divison of gender roles in their families, 2) Increasing gender awareness, considering that emancipation and socialization efforts for gender awareness have been encouraged for a long time, 3) Increasing levels of education for women, 4) Opening opportunities for new interpretations of religious values, 5) Advances in information technology that encourage globalization that enables the absorption of new values and thoughts from other countries and cultures, and 6) Progress and development of the country's economy, which encourages women to engage in economic development by entering public areas.

\section{Attitudes towards representation of women's domestication in the public sector in advertisement}

The research subjects argued that men were more appropriate to be leaders in advertisements because of their position above women. They did not mind if the advertisement described the success of men in the public areas but argued that women should also be described as being able to succeed in the public areas, and not only as servants (Table 7). 
The opinions of the research subjects are thought to be influenced by the strong understanding and belief in patriarchal values, namely that men have dominance (power) towards women and children in their families and communities, their position is higher than women, so men deserve to lead, and women must be led. Patriarchal values are confirmed through the various religions and cultural values (Mufidah 2010, Fakih 1966, Fakih 2010).

In Islamic values, men are leaders for women (Fakih 1966, Muhammad 2001, Fakih 2010, Mufidah 2010). In Javanese culture various expressions place men as leaders and women as led, as in the expression 'wong wadon iku swarga nunut neraka katut' (women go to heaven join men, so if they go to hell), women are 'konco wingking' (friend who moves behind), or also the term woman which is interpreted as 'wani ditata' (dare to be arranged). Javanese culture also sees women as subtle, graceful, neat creatures but who do not have high thinking, and lack spiritual abilities and strength, so women need to get protection and direction from men, and therefore women must submit to men and meet the needs of men and support the desires and interests of men. Conversely, men are seen as protectors and decision makers (Kusujiarti 2006).

Feminine and masculinity stereotypes are also thought to influence the formation of attitudes of research subjects who see men as more appropriate to be leaders than women. Some sources (Fakih 1966, Kasiyan 2008, Mufidah 2010, Fakih 2010), state that stereotypes that are attached to women are generally negative, such as emotional, weak, dependent, indecisive, gentle, passive so that they are deemed, unfit leader. While the stereotypes that are attached to men tend to be positive, such as rational, strong, independent, assertive, active, dominant, so that they are considered worthy of being leaders, masculine stereotypes make men a superior group, while feminine stereotypes make women as second-sex.

The opinion that advertisement should also represent women's involvement in public areas and be able to achieve success as men (Table 7) is driven by the growing awareness of the growing reality in society that women are proven capable of acting and achieving success in the public areas in various functions and positions (Indrayani \& Lisna 2007, Intan 2014). The scarcity of advertisements that describe the success of women in the public areas is seen as an injustice and humiliation for some research subjects.

\section{Conclusion}

This study found that the research subjects saw the tendency of the use of female models in advertising to be fairness and not a problem as long as fulfilling certain criteria. The representation of female domestication in the domestic sector in advertisements is also considered reasonable because what is represented is the nature of women and the reflection of women themselves. However, research subjects disagree if women are only described as mothers who are responsible for housework. The research subjects did not mind if the advertisement described the success of men in the public areas, but demanding women was also described as being able to succeed in the public areas and was not suggested only as a servant.

\section{References}

Abdullah (2006) Sangkan Peran Gender. Yogyakarta: Pustaka Pelajar.

Agustino L (2008) Langkah Besar Perempuan Indonesia (atau Sebaliknya?): Telaah Kritis Perempuan dalam Media. In: Sastriyani (ed). Women in Public Sector (Perempuan di Sektor Publik). Yogyakarta: Tiara Wacana.

Bakir A, Blodgett JG, \& Rose GM (2008) Children's responses to gender - role stereotyped advertisements. The Journal of Advertising Research 48 (2). [Accessed 18 November 2017]. http://www.journalofadvertisingresearch.com.

Budiman A (1985) Pembagian Kerja secara Seksual, Sebuah Pembahasan Sosiologis tentang Peran Wanita di dalam Masyarakat. Jakarta: Gramedia. 
Cresswell JW (1994) Research Design: Qualitative and Quantitative Approaches. London, United Kingdom: Sage Publications.

Courtney \& Lockeretz (1971) A woman's place: An analysis of the roles portrayed by women in magazine advertisements. Journal of Marketing Research 8:92-95.

Duker JM \& Tucker LR (1977) Women's lib-ers versus indipendet women: A study of preferences for women's role in advertisements. Journal of Marketing Research XIV:469-75.

Fakih M (1966) Membincang Feminisme, Diskursus Gender Perspektif Islam. Surabaya: Risalah Gusti.

Fakih M (2010) Analisis Gender dan Transformasi Sosial. Yogayakarta: Pustaka Pelajar.

Ford JB, LaTour MS, \& Lundstrom WJ (1991) Contemporary women's evaluation of female role portrayals in advertising. Journal of Consumer Marketing 8 (1):15-28.

Gornick V \& Moran BK (1971) Woman in Sexiest Society: Studies in Power and Powerlessness. New York: Basic Books.

Hagijanto AD (2000) Figur wanita sebagai penarik pandang dalam iklan. Nirmana 2 (1):1-11.

Handayani TS (2006) Konsep dan Teknik Penelitian Gender. Malang: Penerbitan UMM.

Intan S (2014) Kedudukan perempuan dalam domestik dan publik perspektif jender (Suatu analisis berdasarkan normatisme Islam). Jurnal Politik Profetik 3 (1).

Kasali R (1993) Manajemen Periklanan, Konsep dan Aplikasinya di Indonesia. Jakarta: Pustaka Utama Grafiti.

Kasiyan (2008) Manipulasi dan Dehumanisasi Perempuan dalam Iklan. Yogyakarta: Penerbit Ombak.

Kusujiarti S (2006) Antara Ideologi dan Transkip Tersembunyi: Dinamika Hubungan Gender dalam Masyarakat Jawa. In: I Abdullah (ed). Sangkan Paran Gender. Yogyakarta: Pustaka Pelajar.

Lundstrom WJ \& Sciglimpaglia D (1977) Sex role portrayals in advertising. Journal of Marketing $41(3): 72-79$.

Marwell G (1975) Why ascription? Parts of a more or less formal theory of the functions and dysfunctions of sex roles. American Sociologycal Review 40 (4):445-455.

Matlin MW (2004) The Psychology of Women. Canada: Wadsworth.

Miles MB \& Huberman AM (1994) Qualitative Data Analysis: An Expanded Sourcebook. United Kingdom: Sage Publications.

Mittal B \& Lassar WM (2000) Sexual liberalism as a determinant of consumer response to sex in advertising. Journal of Business and Psychology 15 (1):111-127.

Muhammad H (2001) Refleksi Kiai atas Wacana Agama dan Gender. Yogyakarta: LKiS.

Pawito (2007) Penelitian Komunikasi Kualitatif. Yogyakarta, Indonesia: LKiS.

Ritzer G (2010) Teori Sosial Postmodern. Yogyakarta: Kreasi Wacana.

Siswati E (2014) Representasi domestikasi perempuan dalam iklan. Jurnal Ilmu Komunikasi 11 (2).

Sukri SS \& Sofwan R (2001) Perempuan dan Seksualitas dalam Tradisi Jawa. Semarang: Gama Media.

Suwasana AA (2001) Persepktif gender dalam representasi iklan. Nirmana (3) 2:83-96.

Whipple TW \& Courtnet AE (1980) Sex Stereotyping in Advertising: An Annotated Bibliography. Cambridge, Mass: Marketing Science Institute. 
Wibowo W (2003) Sihir Iklan, Format Komunikasi Mondial dalam Kehidupan Urban-Kosmopolit. Jakarta: Gramedia Pustaka Utama.

Widyatama (2006) Bias Gender dalam Iklan Televisi. Yogyakarta: Media Pressindo.

Yuris A (2008) Estetika dan Mitos Perempuan dalam Iklan Sumbo Tinarbuko. [Accessed 21 September 2010]. http://andreyuris.wordpress.com.

Zimmerman A \& Dahlberg J (2008) The sexual objectification of women in advertising: A Contemporary cultural perspective. The Journal of Advertising Research 48 (1). [Accessed 18 November 2017]. http://www.journalofadvertisingresearch.com. 